\title{
Dark, bloody and savage: Twentieth-century European violence and its narratives ${ }^{1}$
}

\author{
Javier Rodrigo \\ Universitat Autònoma de Barcelona, Departament d'Història Moderna i Contemporània, \\ Edifici B, 08193 Bellaterra (Cerdanyola del Vallès) \\ e-mail: javier.rodrigo@uab.es
}

Submitted: 9 September 2014. Accepted: 31 October 2014

\begin{abstract}
This paper looks at major European twentieth-century narratives and interpretations that have seen it as an age of violence, terror and genocide. Using examples from historiographical debate and the analysis of specific historical processes (including the debates on genocide, concentrationary systems, civil wars and the Holocaust), it addresses both the characteristics of those narratives and some of their limitations and conceptual edges. Finally, the conceptual proposal put forward seeks to analyze, through historical contingency, continuities and discontinuities in the history of European collective violence.
\end{abstract}

KEYWORDS: Europe; genocide; violence; terror; historiography; political science

Citation / Cómo citar este artículo: Rodrigo, Javier (2014). "Dark, bloody and savage: Twentieth-century European violence and its narratives". Culture \& History Digital Journal, 3(2): e014. doi: http://dx.doi.org/10.3989/chdj.2014.014

RESUMEN: Oscuro, sangrante y salvaje. La violencia europea del siglo xx y sus narrativas.- Este artículo propone una mirada a algunas de las grandes narrativas e interpretaciones sobre el siglo Xx europeo que lo han visto como una centuria de violencia, terror y genocidio. A través de algunos ejemplos de debates historiográficos y de análisis de procesos históricos concretos (como los debates sobre el genocidio, los sistemas concentracionarios, las guerras civiles o el Holocausto), se abordan tanto las características de esas narrativas como algunos de sus límites y aristas. Al final, se adelanta una propuesta conceptual para analizar desde la contingencia histórica las continuidades y discontinuidades en la historia de la violencia colectiva europea.

PALABRAS CLAVE: Europa; genocidios; violencia; terror; historiografía; ciencia política

Copyright: (C) 2014 CSIC This is an open-access article distributed under the terms of the Creative Commons AttributionNon Commercial (by-nc) Spain 3.0 License.

Dark, bloody and savage... ${ }^{2}$ It would appear that a description of the Old Continent, at least in the first half of the twentieth century, calls for adjectives that evoke blackness, chaos and death. They likewise apply -perhaps even more so- when we consider, not the century as a whole, but some of the great events that occurred during that period, be they the First or Second World War, deportations or forced displacements. They are certainly relevant, when we look, not at the history of the whole continent, but at some of the countries or regions comprising it, from Civil-War Spain to Liberazione Italy, Nazi Ger- many or Communist Rumania. In the twentieth century, a period of total war and mass annihilation for national, racial, identity or political reasons, states, para-states, groups and state agencies (or those who fought against them) caused millions of victims among war combatants and non-combatants in conflicts of a political, identity or racial nature. The civilian population, in other words the non-combatants, ultimately became -where they were not already- the priority target of groups which, either from their position of power, against the prevailing power or with a view to taking power, took up, launched or piloted 
arms. Although it is obvious that the twentieth century cannot be interpreted exclusively in terms of violence and terror, it is hard to imagine any analysis of the last century without these variables.

Historiographical literature on European violence contains enough common elements for us to contemplate the existence of a kind of great European transnational narrative -relatively recent but increasingly solid- on violence and its politics in twentieth-century Europe. This narrative is characterized by growing attention to the phenomenon of terror, intimidation, expulsion and the homogenization of identity as processes that generated strong historical dynamics, where violence is not merely an epiphenomenon but even the very midwife of contemporaneity. It interprets the twentieth-century in terms of cleansing, expulsion and political, social and cultural elimination, where war and collective violence are no longer the result of a mere collapse of politics, inevitable and intrinsic human processes or trivialized interpretations pointing to insanity or criminality. It is, in short, a history of violence: the violence that drove the rise to power of fascism and antifascism, which was the main vehicle of political action under the mantle of civil and international wars, and which, from First World War massacres to the attempt at racial extermination in the Second, made the twentieth the most brutal, bloody and, consequently, foundational century in the history of the last millennium.

Indeed, more than a few historians consider it the most violent century in the history of humanity, both in terms of the human lives lost as a result of war and racial, political, ideological and identity conflicts, and for the centrality acquired by the discourse, accounts and praxes of violence in contemporary society (Lüdtke and Weisbrod eds., 2006; Bloxham and Gerwarth, 2011; Capeloa Gil and Martins eds., 2012). The twentieth century was characterized by many and very complex phenomena, including uprising, repression, revolution, ethnic conflict and genocide (Chenoweth and Lawrence eds., 2010: 6), but it was also defined by world and civil wars, with their interminable post-war periods, occupations, racial eliminations and large-scale national displacements as well, of course, as identity cleansing (Ahonen et. al., 2008; Lowe, 2012). All of these were processes of extreme violence against individuals and entire groups. From Asia to America, from Africa to Europe, the twentieth century was the century of democracy and science, but it was also the century of revolution and fascism. The century of violence, genocide and terror.

It is certainly reasonable to think in these terms if we are referring to Europe. Violence, systematic elimination of the enemy, identification and separation of the other to protect the community were not, of course, the exclusive preserve of the twentieth century. The nineteenth century was a time of exiles and political deportations, of revolutionary and counter-revolutionary prisons, and of national wars in which civilians played a substantial part. But the qualitative and quantitative scale of the violence of the preceding century is far outstripped by any of the pro- cesses that took place in the twentieth. In general terms, it contained more violence than earlier centuries (pending developments in the current century, see foretaste in Holmqvist, 2014), because the twentieth century had at its disposal better and more effective resources in contexts that were more conducive to inflicting it. In this article, I tackle, by way of incomplete panoptic (out of necessity, since the literature on these phenomena are too vast to be manageable), certain traits of these politics of violence through contemporary historiographical narration -consciously focusing on the first half of the century- with an ultimate view to offering a conceptual proposal (although I shall seek to make this less pedantic than the phrase suggests) which serves to analyze twentieth-century European violence.

\section{NARRATIVES}

War and violence are some of the main mechanisms that define the history of twentieth-century Europe (Baldissara and Pezzino eds., 2004; Gribaudi ed., 2007). And within this history of violence, states, para-states and agencies of power are their main subjects, alongside paramilitarized groups endowed with openly violent and eliminationist political cultures. Political and identity motivations are their main justification. And the enemy -national, class, etc.- who usually non-combatants in the war processes, is its main objective. However, far from being coherent, linear or homogeneous, the histories woven by the narration of twentieth-century European violence, form a confusing mass of overlapping lines, where there is no blueprint or idées forces, a comparison of which must go beyond argumental juxtaposition, and for which simplistic explanations or aprioristic definitions will not suffice: massacre, genocide, politicide and holocaust have ultimately become, not the conclusion of complex and protracted debate but, at times, conceptual apriorisms or mental boxes into which are introduced, and sometimes forced, a much more protean historical contingency than tends to be acknowledged.

The succession of internal and international wars which mark at least the first half of twentieth-century European history, is perhaps the most studied period of contemporary historiography in recent decades, although its study has not always been accompanied by an analysis of the politics of violence implemented in European societies. The array of recent historiography on twentieth-century European violence has, in general, drawn on common characteristics, both in terms of research methodology and to interpret the past. There are at least three such characteristics. Firstly, there is general acceptance of a transnational, and sometimes transtemporal, mechanism -not infrequently decontextualized- of the resolution of human conflict through violence. As pointed out by Dirk Moses, one of the top experts in the field, when I voiced my doubts about the concept's applicability to the context of the Spanish Civil War, genocide is not a historical exception, but an almost constant feature throughout the history of humanity. Secondly, this mechanism - reduced to com- 
parable and repeated behavior in different times and places- is explained using a series of metaphors that take in the perpetrators, the identities of victims and the functionality of violence. And thirdly, the twentieth century is periodized around the watershed of 1945, leaving the second half of the century virtually free of collective violence, which is focused almost exclusively on the slightly more than thirty-year period between 1914 and 1945. The question at stake here is not merely rhetorical, nor is it the fruit of a Byzantine debate: it is the observation that, in the study of violence as a historical subject in contemporary societies and of its usage, assumptions, metaphors, moral and political positions abound, but what is sometimes lacking is contextualization, a precise and complex knowledge of the historical processes analyzed and non-aprioristic theorization.

In reality, the current theoretical tools used to analyze processes like mass murder, genocide and civil war are no more than twenty years old. The changes that occurred in the management of political governance and territorial control after the end of the (so-called) Cold War, together with the globalization of economic resources, led to a necessary sophistication of the means used to analyze contemporary reality, also applicable to the field of collective violence. And, understandably, this growing complexity had, before long, extended to the field of historical analysis. This is apparent if we observe, for instance, the rapid growth in genocide studies since the nineteen-nineties, although theoretical debate and exchange has been rich and intense since the end of the Second World War. Indeed, violence is a central theme in the promotion of conceptual exchange between political science, anthropology, historiography and sociology. Political science was the first to tackle violence from the presumption of predictability, using, in most cases, the notion of political violence to refer to historical (and present) mechanisms of violence with a political nature, explanation and objective. Authors like Parsons (1964), Feierabend (1966), Gurr (1972), McFarlane (1974), Maffesoli (1979), Michaud (1980), Mommsen (1982) and, more recently, Della Porta (1995) have proved, in the theoretical field, the operation of processes like socialization through the symbolic dimension, deprivation or relative shortage, systematic frustration and dysfunctions in the system when analyzing what at that time was called violentology, namely the processes and mechanisms of violence for political motives or in political contexts. But this was almost always with reference to terrorism and virtually never to what historiography has dubbed mass killing, and it had one key objective: prevention.

This is a common topos in the analysis of collective violence, particularly when this comes from the social sciences. As such, it is the result of a strong decontextualization of the elements of analysis - apparently a prerequisite for assuming the predictability of the present and the future through a knowledge of the past. And this is particular relevant to certain historical narratives and analyses. Consequently, even where the contexts are not interchangeable, much scrutiny of the collective violence of the twentieth century has been unable to avoid the temptation to appeal to its usefulness, looking at the present and towards the future because, to a great extent, its authors believe that identifying the elements that have led to violence in the past can avoid its repetition (as in Mann, 2005). To achieve this lofty goal, the world is divided up into categories with a strong metaphorical and/ or purely conceptual component - the people, class, race or the Holocaust. Human action in society is reduced to tables, behavior charts, analytical diagrams and mathematical formulae (such as Kalyvas, 2006), sometimes unanchored in contingency or even at its expense (Goldhagen, 2010:349 divides conflicts into tables, depending on whether or not the enemy was dehumanized or demonized). And there is tendency towards omni-comprehensive definitions or conceptualizations of complex and often distant processes.

The best known, needless to say, is genocide, a term with enormous projection in recent historical studies and, indeed, one of the major macro-categories in the study of European violence (Stone, 2008; Moses ed., 2010; Moses, 2013). As such, it links the definition of the crimes studied with a legal category endowed with imprescriptibility. It is therefore, at least partially, coherent with the demands made by memorialist movements in Europe (and on the American continent), but in historiographical terms, it is much more than a simple history from the victims' standpoint. Indeed, in recent times, alongside the array of theories in genocide studies, it has reached a degree of analytical complexity which amply transcends (as shown in the work by Bloxham and Moses eds., 2010), the aspects posed by the neologism's creator, Raphael Lemkin. ${ }^{3}$ In short, the definition of genocide and its operativeness are open to debate, and for more reason than one.

It is no less important that this array of theories should have been made on the basis of inclusive definitions, through which it is complicated -or, depending on your standpoint, extremely simple- to establish where or what a genocide is and where or what it is not. Although there are possibly no two theoreticians who coincide in every respect, in the most recognizable aspects of processes described as such, genocide is said to be the result of barbaric, external, unexpected and extreme aggression on a particular category of innocent, defenceless victim which is a racial, religious or national population group, according to the terms of the 1948 Convention; this has infinitely more complex in recent studies, where this victim group is identified and stereotyped by another population group, namely the perpetrator (Shaw, 2007). The violence inflicted is said to have forms, causes and consequences which respond (or should respond) to a mechanistic, preestablished and omni-comprehensive dynamic, to a global and recognizable plan to eliminate this category of victim. Consequently, in such processes, mass killing, elimination and forced displacement are considered ends in themselves: eliminating, possibly involuntarily, the relational nature of mass killing, that element of violence which generates processes of terror and explains, among other things, political repression. 
It is therefore a question of name, but also of interpretation. And it carries with it a cosmovision of the past, its processes and subjects. If we accept general theories on political violence, terror and genocide, the first and greatest perpetrator to be found in twentieth-century European violence is generally the state (Schmid, 1991; Horowitz, 1989; Rummel, 1994), either in confrontation with other external states or in conflict with internal elements. However, the state form of power is not the only one. Immersed in these processes, we also find para-states (such as those in civil wars), agencies peripheral to the state (like the Croatian Ustaše), potential or parallel states (like the Nazi SS), states in construction or reconstruction (such as those of post-war eras) or those who are fighting against the state, armed military groups (Italian or Yugoslav partisans, the Chetniks, the EAM-ELAS or FTP) or terrorists (the squadristi, the Brigate Rosse, the IRA, ETA). And of course, we find not only leaders, but also local and territorial agencies of power whose criteria do not always coincide with that of the state (Kershaw, 2005; Chenoweth and Lawrence eds., 2010). We will find collective stakeholders who, in the slippery terrain of collaboration, may be both victim and executioner, and we also find individual stakeholders (Jensen and Szejnmann eds., 2008) with their own non-transferable criteria. Finally, we will find criteria that do not strictly operate at the state level. The nature of National Socialist, fascist or revolutionary political and racial violence, for instance, is not defined only by state interests, but, above all, by the construction and protection of communities of people and nations, of racial, national or class homogenization under the auspices of violence and its use. In the context of civil war, the interaction of multi-directional violence sits uneasily with the theoretical patterns of unexpected aggression among identity macro-categories.

There are, then, highly significant nuances to the conclusion that leads the state and its criteria to be, respectively, the sole perpetrator and legitimizer of collective violence. Indeed, there is no ideal combination of factors. There is no single, transtemporal and decontextualized violence; no violent, monocausal ideal type. The most widespread kind of analysis in genocide studies, focused on the search for ideological, racial, religious or construction factors of state entities, which compares a process of violence with a genocide ideal type, tends to have difficulty when used in empirically-based analysis. Through geopolitical, identity or cultural analysis, the seizure of power or its maintenance may ultimately emerge as minor variables when attempting to understand mass violence. Historical contingency reveals fewer structural than contextual factors in a comparative study of these processes. Indeed, it is not that the ideal combination of state-intentionality-planning -which, added to the necessary condition of defined victim, is established as a prerequisite for the 1948 Convention definition of genocide (the definition mainly used in Spain owing to lack of awareness of the work by authors like Bloxham, 2008)does not appear beneath the surface of reality. But it is rather that, as if caked in apriorism, this ideal combina- tion surrounds knowledge of the past. Perhaps, more than homicidal intentionality, we ought to refer to amorphous processes, devoid of blueprint or idées forces. Consequently it is debatable whether we can use the same denomination, namely genocide, for different processes in distant contexts.

Put another way: there is less evidence suggesting imitative effects between different power systems than that which points to the feasibility of understanding each phenomenon of violence in its own context. Analysis of their respective criteria reveals a greater importance of local and regional dynamics than the application of a supranational logic, however many common elements they may share in terms of interests of class, identification and stereotyping of the enemy and in the application of violent political purging and cleansing mechanisms. The materialization of power in forms of violence is usually related to contexts of war or acute internal tension. Also, the progressive conceptualization of civilians as a priority war target, and the blithe and unthinking dissemination of ideologies exalting violence and death are certainly among the dynamics that did most to promote that. The factors of modernization and accumulation resulting from industrialization, and, in general the economic structure (rural and/or urban) are, when seen in perspective, key to its practical materialization: undoubtedly in the few phenomena of revolutionary violence in Europe, but also in the identification of certain social categories as dispensable (the European Jews, as a case in point). But, as rightly pointed out by Christian Gerlach (2010: 1-9), all this preparation, all this accumulation of determining factors need not necessarily lead to a process of collective violence.

There are, of course, common dynamics. More precisely, such processes mainly take place in contexts defined by severe conflict praxes and crisis perception (Gerlach, 2010: 267). Moreover, if we consider twentieth-century Europe, they also take place, on the whole, over periods of time that are not excessively long. There are, of course, long periods of political repression, of structural subjugation to the reality, or potential threat, of violence, and the cases of Spain and Portugal are good examples. But if we take a closer look, we will see how collective violence tends to take place at specific moments, rather than over indefinite periods of time. It has precipitation processes in times of crisis, and in Europe the periods of all-out war undoubtedly stand out as being such, and they ultimately have a broad factual, rather than potential, range (killings, deportations and forced exile). Indeed, collective violence cannot be reduced to the condition -albeit most relevant, but also most extreme- of killing. In their role as a part of broader transformation projects, processes of collective violence -interrelated to varying extents- could be implemented to different degrees, ranging from unfair discomfort to collective extermination, and including repression, selective terror and mass terror.

Though not infinite, the repertoires in question are diverse, numerous and even imaginative. They cover not only killing and abuse, which is sometimes extreme: violence (the action) and terror (the effect) do not always end 
in death or even have death as their aim: mass violence is not just extermination, but involves a much broader concept than mass killing (Thrift, 2006). Were we to leave out of the actions we understand as mass violence, all those that are not accompanied by death, either by action or by omission, we would not include exile, deportation, torture, political repression, forced imprisonment, persecution, beating, forced impoverishment, rape or many others. Yet the Squadistra violence of early Fascism, using castor oil and the Fasci campaigns in Northern Italy, was less murderous than intimidatory. Internment in the savage camps of the Nazi Germany of 1933, or the Spanish and Portuguese work camps did not pursue the death of their prisoners. Nor was this the aim of the rape and public humiliation of left-wing women in the Spanish Civil War, or of the collaborators during the liberation of France. Many of the half a million Spanish people exiled also died, but they were not killed. Thousands of the up to 12 million Germans who were expelled or deported from Eastern Europe after 1945 also died. The exiles and deportations meant mass displacements of individuals characterized by a precise national, political and, to a great extent, ethnic-linguistic identity. The death of the displaced persons was not deliberately sought. And yet, we would be hard-pressed to leave this deportation, rape, humiliation, internment and exile out of the analysis of what violent praxis in the twentieth century is and represents. Indeed, scholars studying the nineteenth century -when there were civil and international wars, political reprisals and imprisonments, but no extermination camps or atomic bombs- would, to say the least, find such an approach grotesque.

Europe (central, western, eastern, southern and northern) is the laboratory where violent progression and the dynamics of contemporary destruction become more apparent, as it is the ground on which -unlike the United States of America, whose interventions on foreign soil give rise to reflections along lines of cultural continuity, as in Dower (2010), Black (2012) or Atanasoski (2013)most wars took place, and did so on a more continuous basis, in the nineteenth and twentieth centuries. Without war, rates of violence are always considerably lower. The killing of the Armenian national minority in Turkey required no war context in 1894-96 or in 1909, but the way in which it took place (identification of the national minority as the enemy and the ally of Turkish enemies, deportation and mass death) required the legal and functional context of the global war (Dadrian, 1995; Melson, 1992; Akçam, 2004; Kévorkian, 2006). In Spain, the rate of killings as a result of political persecution, and other indicators of collective violence, such as concentrationary systems and forced labor, dropped substantially in 1948, after the end of the state of war initiated in 1936. Throughout the protracted age of Fascism, the greatest violence, in quantitative terms on Italian soil, took place in the context of the Second World War, and of the Civil War and Liberazione. Indeed, Italy is a clear example of these radicalization mechanisms. Violence in Mussolini's Italy was not limited to the millions of accusations or the hundreds of thousands of arrests that took place in peacetime, but also included a diverse range of violence of a political, colonial and racial nature. ${ }^{4}$ However, despite the clear and explicit evocation of permanent violence, its policy of violence was quite substantial, and quite on a par with those of its neighbors, especially in times of war: the period of military internment, anti-Slav policies in the Balkan region under military occupation and the Jewish deportation. Europe's major collective massacres have, then, taken place under the auspices, or as a result, of war processes, and in these contexts, non-combatants have been their main objectives. It is true that, when seen in a global perspective, genocide and mass killing are not and need not always be related to the war contexts themselves. The Ukrainian Holodomor 1933 (Naimark, 2010) or the massacres in Maoist China, including hundreds of thousands of Tibetans in 1950, were not directly related to a military confrontation. However, if we turn the spotlight on Europe, we will reach a different conclusion.

\section{CONTINGENCIES}

When considering mass violence in twentieth-century Europe, it is crucial, as Mark Mazower (2002) recalls in an influential article, to make historical contingency our starting point. This does not mean foregoing theorization. Quite the contrary, historical contingency must serve -unlike in the works of authors such as Midlarsky (2005), Slim (2008) or Valentino (2004) - to modulate, complete and enrich it. Theorization requires a painstaking prior reconstruction, an informed study of contextualization and a sophisticated attempt at comparison. Rather than a conceptualization of violence as a decontextualized mechanism suspended in time and space, historiography must offer an analytical framework that does not set aside spatial, temporal or contextual dimensions. Pace of development, asymmetry and spatial differences cannot be underestimated. Nor can we reduce mass violence to pathological mechanisms or forget that it can be a mechanism or an end, it can be a tool or have a nature of its own, but it always has a purpose and objectives. It must, in short be contained. And if, instead of gazing through the looking glass of empirical demonstration of a previously-developed theory, we contemplate the contemporary past of violence through historical contingency (clearly historiography's most relevant contribution in this field), we will observe that the twentieth century was extremely violent, owing to the global accumulation of multifactorial historical processes, each in its own set of circumstances and context, which were not necessarily exclusively national or endogenous but were, in short, its own.

A combined analysis of collective violence in twentieth-century Europe, which I only refer to here as an interpretative proposal, must be considered in a series of different lights. The first is to assume the impossibility of covering all the different, complex and multi-layered processes of violence on the Old Continent. The second is to heed historical contingency before theoretical development in order to be able to observe the dynamics of conti- 
nuity and discontinuity in the circumstances that promoted this multiplication of violence praxes. The third is to observe how rates of violence in Europe rose exponentially as a result of the concurrence on its soil of the phenomena of fascism (Kallis, 2005), war of occupation and civil war (Rodrigo, 2014), with this multiplication of conflicts contributing, in turn, to the multiplication of the intensity and depth of the politics of violence in Europe implemented against a stereotyped, supra individual enemy which was, moreover, in most cases a non-combatant civilian. And the fourth is not to bring explanation to a halt with the cessation of hostilities in 1945, avoiding that clear-cut division which often prevents us from noticing that the end of the violence after Second World War was not an occurrence but a process, into which rupture and continuity were interwoven, and in which the criteria of violence were gradually or abruptly replaced in the second half of the Forties.

Even so, the very notion of the twentieth century is not totally clear cut, at least where this issue is concerned, and particularly, if we analyze the origins, in chronological terms, of the rise in violence defined in the contemporary way (in wars, against civilians, motivated by power and identification of the enemy on racial, economic, political or identity grounds). Continuing a tradition started by Hannah Arendt (1974), war and cultural elements have been identified that enable us to find the roots, background and even origins for particular types of violent behavior by the state (including the annihilation and political purge campaigns orchestrated by the rearguard during the Spanish Civil War) in colonial practices (Morton, 2013). Mass deaths like those in the Java War of 1825-30 (some 200,000 villagers killed by the Dutch army), those in Algeria in 1840, the decimation of the indigenous population of California from 85,000 to 35,000 people between 1852 and 1860 , the death of more than 100,000 indigenous people in Mozambique at the hands of the Portuguese army in its conquest of the island's interior at the turn of the century, or the almost 11,000 Sudanese warriors killed by the British army's machine gun fire in 1898, are interpreted, wholly or partially as genocide, perhaps stretching the usage of this complex category, traversed by historical, legal, sociological, anthropological and moral assumptions, the disproportionate use of which sometimes responds more to the import of conclusions than to the debate about this usage. One case, however, is particularly striking, namely the extermination by German troops of the Herero people in South-West Africa between 1904 and 1906 (Sarkin, 2011). Since 1884, the indigenous Herero people in Namibia had been subjected to confinement, to the occupation of their lands, to segregation and eradication of their basic rights. The failed uprising against German farmers of 1904 is said to have triggered the measures taken by the troops led by Von Schlieffen to deport to the desert a population that was already decimated and which, in the course of the process would be reduced from 80,000 to 16,000 people. The identification of the eliminated population, the constant and cumulative nature of the segregation, exclusion and expulsion policies and, ultimately, the mass character of the elimination practices suggest this to be the first contemporary genocide and, possibly, the only one that can reasonably be defined as such in the colonial context. Colonialism in Africa and Oceania was terrible for the vast majority of the colonized populations, implying violent pacification rather than peace, as well as labor exploitation (essentially in agriculture and on the railways) and the large-scale propagation of disease. But, except in the case of the Herero extermination, to refer to these cases as genocide (as in Stannard, 1992) is to reinterpret and redefine the term to such a degree as to render it virtually inoperative.

More than genocide, the main thrust of contemporaneity would be collective violence, essentially developed in times of war and, within it, against non-combatants. In this sense, historiographers are virtually unanimous in placing the origin of the era of contemporary terror in the Great War. The 1914-18 War was a war of generalized and definitive violation of nineteenth-century war rules and principles, with the bombarding of civilians, economic blockades, territorial occupation and forced labor of non-combatants. It therefore reached dimensions previously unknown on the scale of contemporary violence. ${ }^{5}$ The Great War entailed a new, highly lethal and acutely dehumanized form of armed combat. But within it, it also contained overlapping conflict processes and violence between which the interconnections are not always made. The aspect of the War's numbers, however, remains a slippery slope, as too is any attempt to distinguish between combatants and non-combatants in all-out war. And if to that we add the fact that warfare technology was infinitely superior to information and knowledge technology (in short, it was easier to kill enemies than get to know them), we come up against the obvious difficulties involved in working out real and effective casualties, divided and separated by categories (both real and analytical), which are nonetheless crucial to gauge the significance and impact of the Great War. The accepted global figures stand at around nine to ten million dead soldiers (of the 70 million mobilized) and 25 million injured. Every day, 1,300 Germans and 900 French died. But exactly what proportion were combatants and civilians? For Mann (2005), the proportion of civilians who died in the Great War did not exceed the 10\% proposed by Chestermans (2001). Mc Millan (2011: 46) believes it to be 5\%, compared to $66 \%$ in the Second World War. And all of these figures contrast with the $30 \%$ proposed by Alan Kramer (2007; with Horne, 2001), currently the major expert in everything connected with prisoners of war, the deportations of civilians, concentrationary systems and forced labor in the Great War. His seminal work has highlighted the way in which the repertoires of violence in the Great War went beyond what can strictly be considered war and did not only consist of the killing of soldiers and military personnel. Indeed, a central element in recent studies is the extension of the repertoires of what should be considered practices of violence in the context of occupation policies, as inflicted both on soldiers and on the civilian population (McPhail, 1999; Procacci, 1999). 
The processes of internal violence which the Great War fostered and helped create (deportation, ethnic-national homogenization or internal wars) would also elevate indices and figures to hitherto unknown heights. A good example of the significance acquired by these repertoires of violence was in the rise of internment and concentration camps of prisoners and civilians. From the early weeks of occupation, faced with the shortage of manpower, civilians were the parties most affected by the deployment, firstly of forced labor, and later of camps where they would be interned (Becker, 2007). Thus it was that the Great War came to maximize both the functionalist use of concentration camps as a war-administrative unit, and their perception as a cheap and plausible, preventative and arbitrary, anomic and adaptable means of meeting the needs created by the massive numbers of war or political prisoners in the hands of state or para-state units, of converting internees into exploited agents. The violentization of political practices and the massive nature of the political divisions resulting from or as a consequence of the six-year period from 1917-22, would do the rest to establish the premises of the new type of camps -the ultimate expression of political violence, imposition of the divider and suffering for political, social and ideological causes.

Yet it is remarkable how processes of such magnitude as the revolution in Russia, the Civil War in Finland or the elimination of the Armenian minority in Anatolia are so often taken out of their war context. During the First World War, Armenians, Greeks, Assyrians, Chaldean Christians and Kurds in the Ottoman Empire died in processes of forced resettlement and massacres of different kinds. Indeed, in recent years, quite a few scholars have wondered about the relevance of analysis focused on continuities, learnings from military praxes or the generation in a colonial context of practices of unlimited collective violence (Dwyer and Ryan eds., 2012). No fewer have pondered the historical caesura and pedagogy of extreme violence which the First World War meant for Europe, a conflict on an unknown scale which turned violence into a fulcrum of the contemporary European age: a factor in national construction, community identification and social purification, as well as a mechanism for action on the issue of minorities.

The Great War was a fundamental tipping point in the configuration of ethnic-national identities and in the creation of a new framework, that of all-out war, propitious for their resolution (Roschwald, 2001; Núñez Seixas, 2001; Sanborn, 2005: 290-324). The genocide of Turkey's Armenian population, the first in what Hobsbawm called the short twentieth century, (with the levy of identification taxes, forced displacement, confinement and killing) points precisely in this direction, the same direction as the civil wars that broke out in Russia and Finland in the heat of the World War, conflicts that arose in the context of total international war, invasion and rearguard purges. The war that continued until 1923 between White and Bolshevik Russians, counter-revolutionaries and revolutionaries on the basis of the criteria generated in 1917
(Payne, 2011), made it necessary to design the seizure and maintenance of revolutionary power in an armed context, putting to the test the space which both contenders reserved for political purges, cleansing, repression and the exploitation and/or elimination of the adversary (Figes, 2000: 690; Swain, 1996; Brovkin, 1994; Mayer, 2001; Mawdsley, 1987). This war is of key significance when constructing a cosmovision of twentieth-century Europe focused on the politics of violence implemented in its states: the Russian Civil War was the context which gave rise to the Red Terror and to institutions like the Cheka and the Gulag.

A good example of its paradigmatic character and its scope in the field of contemporary narration on European violence can be found, in fact, in the Soviet concentration camps, which arose out of the experience of the Russian Civil War and in the context of totalization of war in the Great War, which swiftly shifted towards a predominantly political and social use, and whose raison d'être lay in forced labor, especially after Stalin's rise to power and the implementation of his economic plans, which envisaged massive use of prisoners, "asocial" persons and dissidents for labor. This is not a short-sighted or schematizing conceptual homogenization, nor does it have anything to do with the reductionist description according to which the Gulag is supposed to be the fons et origo of Auschwitz. In a theoretical model, the inter-relationship between both phenomena can work, because the Soviet camps preceded their fascist counterparts chronologically, were born of all-out war, revolved around punitive forced labor and served as the space for political repression. There is therefore a reasonable and legitimate doubt which should not be attributed only to an attempt to relativize the phenomenon of the German Lager or to ideological exaggeration. Precisely for this reason, they need to be studied in depth, to distinguish them better and, in this way, identify more clearly the fascist pattern of the European camps. The Soviet camps were established in a society and under political, social and identity premises that were radically different from those in the Europe that gave rise to fascism. They were, under no circumstances, centers for the extermination of civilians: the death of approximately three million of them on the Gulag archipelago, out of the 18 million who passed through it (Bacon, 1994; Applebaum, 2004; Davies and Wheatcroft, 2004), indicates that forced labor, albeit in extreme conditions, was not a systematic, supra individual and preventative practice of extermination. Compared to other overtly exterminatory Stalinist policies (the dekulakization or starvation in Ukraine in particular), the Gulag was not an eliminationist space however brutally re-educative it may have been.

The fact that genocide was practiced in the USSR or that it was a society that was violent in the extreme, as indicated by Gelarch (2010), does not mean that either its political or ideological ethos was similar to that of the European fascists, or that its re-educative, homicidal tactics were comparable. In many cases, the harshness of Soviet labor exploitation far exceeded that of the fascist camps. 
What the chronological and interpretative similarities essentially tell us, is about the versatility of concentrationary spaces. And a comparative study of these, and of the eliminationist practices of the different societies, will also define big enough differences for us not to assume direct continuities, even in a strictly theoretical framework. The Gulag operated more and better in peacetime than at war, and it was a mechanism that ran parallel to that of the political, social and national repression of the republics that made up the USSR. Nonetheless, it did reproduce the historical ruptures regarding internment and forced labor to which the Great War gave rise. Indeed it might be said that they became its paradigm, and even its enormous distorting mirror.

In fact, global wars tend to contain processes of internal facture within, as is apparent if we analyze the Second World War and, to a lesser extent, the First. Yet World War I marked the birth of the European civil-war era between 1918 and 1947 and, likewise, of some of the elements that help explain its virulence, essentially the macro-categories of revolution and counter-revolution. ${ }^{6}$ In both cases, the figures relating to the politics of violence, cleansing and purging serve not only to demonstrate the difficulties of distinguishing between death and killing, and between civilians who were executed or died as a result of war conditions, but also to confirm that the context of the Great War in which both took place, contributed greatly to the "why" (defined by two dimensions: fragmentation and sovereignty), to the "who" (local and supralocal stakeholders, civilians and armies, as in González Calleja, 2013: 138) and to the "how" (internments, occupation policies, forced labor, civilian killings) of the internal violence. In general historiographical terms, it would seem obvious that the massive nature of the crimes of both the First and Second World War brings the historians of 1914 to a new dimension: aware that the notion of the contemporaneity was born in the Great War, they see themselves driven to project on to the past ethical-interpretative categories through which a large part of historiography has reread the recent past. The resulting impression is that analysis, when done from front to back, taking for granted and as recognized the birth of the fascist, eliminationist alternative in Europe, bestows much more importance on the results of the war than on the war itself. It consequently leaves the war, if not entirely void of content, at least reduced to a merely necessary condition, an entry point for the interwar opening: for the Auschwitz era. It does so, however, not without difficulty.

Indeed, one of the great debates around contemporary violence revolves around its representation and the limits of that representation. Whereas the central topos of the political science debate is prevention, the cultural studies debate considers representation. Historiography, in the meantime, has occupied a contentious space in this field as well, since, until recently, the issue of violence was interpreted and considered through the subject areas of anthropology and philosophy, but very little was reconstructed in historical terms. A number of examples, including Katz (1994), Millen (1996), Wiedmer (1999),
Smith (ed.) (2002), Clifton Spargo and Ehrenreich (eds.) (2010), Jacobs (2010) or Aleksandrowicz-Pedich and Pakier (eds.) (2012), to name a few, underscore the symbolic significance of a process, namely the process of deportation to death camps between 1942 and 1945 (indeed much less importance has been attributed to in situ killings by Einsatzgruppen between 1939 and 1942) in the configuration of a transnational memory that is not without its shadows and which is often constructed without taking history into account (a subject, tackled in its full complexity in Stone (2012). The historiographical tradition focused on the machinery of extermination, plunder and the predatory behavior which Nazi territorial occupation policies entailed and, after 1942, the direct death centers that fell under the scope of what was known as Aktion Reinhard, is one of the richest and most complex in Europe, the USA, South America or Israel. But as such, it has been the source of some of the most intense debates, in relation not only to the progress made in general, regional and local research on the extermination of Jews, Slavs and other minorities, but also in connection with extrascientífic processes and events. Discussions such as those on intentionality, comparability, contextualization in the most extensive political and social project of fascism, or its Jewish specificity and uniqueness -an aspect upheld by an ever decreasing number of scholars, such as Weiss-Wendt, 2008: 43)- have fuelled, and continue to fuel, some of the major debates on the contemporary era in philosophical, legal, sociological and anthropological fields, to name a few.

In recent years, the trend has been, on the whole, to decouple the extermination from its uniqueness and place it in direct relationship with the ideological and political framework of German fascism - thus we find, as Tim Mason anticipates, close similarities and, consequently, interpretative paths, between other models, ideological approaches or national policies and fascism. The prevailing perspective then, in the analyses of the last decade is that of victimizer more than victim. And this is despite the fact that the memorialist source is sometimes the only one with which to discover histories that are essential to the process of the Final Solution. There are aspects of the Holocaust about which there is no explicit documentation, but only euphemisms and, at most, memories. An obvious example is the history of the Sonderkommandos, the groups of Jews used to drag their fellow co-religionists to the gas chambers, remove the bodies, burn them and clean out the murder facilities. The final victims referred to by Saul Friedländer (2010) in his books, after close on two thousand pages of highly intense reading, are about twenty children aged between five and twelve, killed after a year of medical experiments, the same day that Hitler was celebrating his final birthday in his Berlin bunker, at the same time as, outside with bombs falling all around, the Reich was disintegrating. No traces could be left, no loose ends untied, no future: at least a million and a half of the Tercer Reich's Jewish victims were less than fourteen years old. It was this pursuit of exhaustiveness that enables us today to talk about genocide, an ac- 
count of which can only be constructed, for many aspects, through memory.

When it comes to looking for explanations for so much death, on the other hand, Shoah literature reproduces the eliminationist drift and Judeophobic intentionality of the racial and anti-Semitic policies of the Nazi regime, successfully putting to the test the framework proposed by Hannah Arendt (identification-exclusion-plunder-elimination) to analyze the mass killing of civilians, be they Jews from Eastern Europe or Armenians in Turkey. Nothing strange about that: after all, the extermination camps were no more than the final link in a chain constructed in times of peace, with measures, laws and acts that are openly discriminatory against entire sections of the population and which, in times of war, served to end the lives of hundreds of thousands of people, as a result of territorial occupation practices in the East. And this is where the weightiest part of their argument lies: in continuity. Once again, this is not without its difficulties. The memory that prevails in the Shoah account is Jewish, even though the first inmates in Nazi camps, as early as 1933, were Communists and political dissidents, the occupying troops in 1941 also killed thousands of non-Jewish Polish, Ukrainian and Belarusians, and the gas chambers were the place of the murder and the crematoriums the place of disappearance of hundreds of thousands of Slavs and gypsies, albeit the latter were killed during a brief period of time. The place where most Jews died, in Poland, had not undergone all the political, cultural and identity developments of the Tercer Reich in peacetime, from the first laws of exclusion of 1933 to the ghettoization and Kristallnacht of 1938, and including the racial laws of 1935 . The correlation between Jewish persecution in Germany in peacetime and the killing of Europe Jews in Poland in wartime ultimately does not convince, and at times appears teleological.

The singularization for its majority condition of a process which was, in fact, universal, is therefore something of a paradox. The absolute destruction perpetrated during the Second World War by the National Socialist regime thus ceases to be interpreted in terms of "total irrationality", "annihilation for annihilation's sake" or "collapse of civilization" and comes to be observed within a brutal logic of racial relocation and reorganization, or "negative demographic policy" (Aly and Heim, 2002: 3; Aly, 1999). Too often seen as a process with two players, namely Germany and the Jews (Stone ed., 2012), this supposed dual relationship actually took place mainly in Poland. Up to half of the victims were in fact killed in their own place of residence. The German policy of violence spread across many strata of occupied society, for political and war reasons, such as with the partisans eliminated under the Nacht und Nebel program, or on racial grounds, as in the case of the gypsies. And when there were extermination camps, those who were gassed were Jews who were also Hungarian, Polish, Belarusian, Italian, Estonians and French. Or they were all of those things and also Communists, Russians or Soviets (Snyder, 2010).

This new historiography on Nazi violence therefore interprets the Second World War, and more specifically, the breakdown of the Eastern Front, as the necessary facilitating framework, the historical opportunity that would have been unimaginable for Goebbels in peacetime, to implement what was to become the Tercer Reich's great sociopolitical project - genocide and racial relocation in Europe (Bartov, 2008). In short, from these analyses, we can deduce that the genocide, the Final Solution, cannot be understood only from the point of arrival, namely Auschwitz, but we must also take account of its starting point: Germany, Poland, Lithuania, the Warsaw and Lodz ghettos, Ukraine and Belarus, Paris or Rome: in fact, up to half of Holocaust victims were killed in their places of residence in mass extermination operations in which the whole community took part and from which many people benefitted. We can deduce too that the extermination camps, the death machinery for which the cogs were suitably oiled at the famous Wannsee conference, were born of economic necessity (the difficulties of feeding the Germans properly, says Aly quoting Gelarch, encouraged the genocide of the European Jews, 2006: 202), but they were also the result of a desire to find an efficient and industrial system of human elimination, rather than the more rudimentary one developed by the Einsatzgruppen in partnership with the local population. We can also deduce that the genocide united and gave scientific, racial, economic, political and military coherence to the different political and ideological projects (political repression, racial biologism, anti-Semitism) of National Socialism, understood as a social and political project and therefore of a comparable nature. And, in short, that the extermination was not only of Jews, but that there were also hundreds of thousands of civilians who were not killed for their Semitic condition (not to mention the mass killing of partisans and war prisoners), as well as the killing of around three million Soviet war prisoners (in total figures, around 930,000 survived of the more than 5,700,000 detained).

This last genocide would frequently appear to pale in significance beside that other great genocide, the Holocaust. They shared chronology and victimizer, often also arenas of execution, and, according to some historians, intentionality. But what they do not share today is the same debating arena regarding history and collective identities. Too much Holocaust kills the Holocaust, critiqued the late Tony Judt in his acceptance speech when awarded the Hannah Arendt Prize in 2007, suggesting that too much attention has been paid to the Jewish specificity and particularity of the genocide which Hebrew tradition calls Shoah, perhaps leaving out millions of nonJewish victims caused by the German occupiers, their allies and satellite governments or collaborators in the heat of their expansion policies throughout Europe, and the territorial and historical contexts of their killings: these include the Balkans (Biondich, 2011; Korb, 2010; Trifkovic, 2011; Yeomans, 2013; Tomasevic, 2001), France (Mazower, 2008) and Italy (Klinhammer, 2006; Pezzino, 2007; Battini and Pezzino, 1997; Fulvetti and Pelini eds., 2006; Baldissara and Pezzino, 2009; Rovatti, 2011). Both an internal conflict and, at the same time, a 
war on the Tercer Reich's southern-European border, the Italian war of 1943-45 and its debates represent a counterpoint to the Judeo-centric vision of fascist violence. In this respect, it is not by chance that, in a climate of internal war, occupation and fascist radicalization, with threeor four-way slaughter and revenge (fascists, antifascists, Germans and allies), a phenomenon could have taken place like the deportation of Jews and partisans to labour and extermination camps in Eastern Europe (Mayda, 2002; Matard-Bonucci, 2008). Neither in Italy nor any any other place in Europe were the deportations an exclusively one-way phenomenon with two subjects. They were also internal and, even more so, intracommunity processes, in terms of both victims and aggressors.

This gives us clues as to the openly vengeful nature of the collective violence in the post-Second World War period: that of the groups massacred during the war, that of Soviet soldiers against defeated enemies or of partisans and guerrilla groups. Harboured within the world war were national wars, taking place at different paces and under different criteria which, in turn, provided a framework for violence armed with their own criteria, and over this was layered the violence of the world war. The violence of war, projected into the time immediately after the conflict, sought an ejecting, homogenizing effect (Deák, Gross and Judt eds., 2000). Europe's purging and defascistizing processes, a full-scale violent political cleansing, also generated some 10,000 victims in Italy and 9,000 in France, the highest and most widespread rates of political detention ever seen in Europe (Dondi, 2004; Lottman, 1986). The de facto disappearance of the problem of minorities took place in a propitious context of extreme internal violence: Poland is a paradigmatic case, to the extent that it saw its national complexity virtually reduced to a state of homogeneity, with the total or partial disappearance within its borders of Germans (from 2.3 to $1.4 \%$ of the population), Ukrainians (from 13.8 to $0,7 \%$ ) and Belarusians (from 5.3 to $0.6 \%$ ) (Mazower, 1998: 463). But it was by no means the only example: in addition to the expulsion and resettlement of the Germans of Eastern Europe, between 12 and 13 million people, other significant cases included the 90,000 Hungarians expelled from Czechoslovakia, or the 73,000 Slovaks ejected from Hungary (Judt, 2005). The expulsion of the Germans to the east of the Oder-NeisseTrieste line, and the national and class resettlement would, in any case, have caused internal conflicts of a national, ethnic, political and economic nature in the countries occupied by the Red Army on the western border (Cattaruzza, 2010). The same can be said of the so-called civil wars on the western borders of the Soviet Union between 1941 and 1947 in what were the death throes of the extremely violent, ongoing confrontation between fascism-collaborationism and communism.

In Germany, as has been documented by Giles MacDonogh (2007), more than three million people died as a result of occupation policies. Plunder, internment in camps and expulsion were the mechanisms used in a denazification process of which civilians were the prime target. This was punishment for the benefits the Germans had previously reaped from the occupation and exploitation of Europe. The post-war world was therefore a time of readjustment, of human relocation, displacement, cleansing and detention - the result of the different, overlapping occupation and civil wars that Europe underwent. The presence of the Soviet army (Faraldo, 2011) in Eastern Europe, as an invasive agent subject to a paradigmatic policy of violence (to the extent that it combined the violence of war, political repression and external invasion), also fostered the outbreak of a new era of violence in Europe, where war on its own soil ceased to be the main vehicle for national construction. The end of the Second World War also marked the closure of the logic of civil war between revolution and counter-revolution: no regime was defeated in Europe between 1920 and 1945 by a Communist or Socialist revolution.

The last of the great European civil wars of the first half of the twentieth century took place on Greek soil and, when seen in perspective, marked a turning point which introduced the logic of the (so-called) Cold War (Gerolymatos, 2004; Voglis, 2002; Mazower ed., 1994 and 2000; Kalyvas, 2000 and 2006). When the Greek Civil War ended in 1949, the whirlwind of war -either civil or international- would not return to European soil for several decades. But that end to violence can by no means be said to date from 1945. The end of the violence, if it ever really happened, would not arrive in Europe until many years later, once the structural opportunities for the politics of violence closed: in other words, when fascist dictatorships disappeared (and in Spain, the debate continues as from when that disappearance actually dates), when the possibility of the territorial occupation of other European countries ceased to be considered (bearing in mind that Western Germany was occupied until 1949), and when continental wars, particularly the internal ones, stopped being a political option.

This is not to say, of course, that violence vanished. The French wars in Madagascar and Algeria, the British in Kenya (in which the vast majority of those who died were civilians), the Spanish in Ifni and the Portuguese in Angola, Guinea and Mozambique, all suggest that this whirlwind of praxes and politics of violence merely displaced the eye of the storm once again to those places where extreme heterophobia had started up, namely the African continent, in the shape of new kinds of globalized war which extended as far as Eastern Europe (Kaldor, 1999; Moore, 2010). And when it finally seemed as if terror was over and that History, in her painful labor process, had finally abandoned her blood dialectic and considered her journey over -having reached what Francis Fukuyama called the end of History- wars returned to contradict those who had said that Europe would not see terror within its borders again. Not, at least, of the intensity attained during the Second World War, but certainly on a par with many of the conflicts that marked the last century in Europe. The widespread image of a Europe hijacked by terror until 1945 and redeemed from violence in the second half of the twentieth century is mistaken and, above all, extremely complacent. To think that 
heterophobia and its expression through politics of violence was over proved, with hindsight, to be irresponsibly naïve.

\section{CONCLUSION}

The superimposition of wars and internal conflicts made Europe a fragmented, dark, bloody and savage continent. The civil wars between 1918 and 1947 and the world wars between 1914-18 and 1939-45 were, in fact, wars comprising superimposed processes, a phenomenon which always gives rise to conflicts of great violent intensity towards non-combatants. This also explains why the reprisals and violence extended beyond the end of the armed conflicts themselves. It is therefore reasonable to think of the twentieth century as the most violent in European history. It was the most violent because after the end of a war -which its contemporaries referred to as Great War and World War because they knew of no other examples of comparable dimensions- states and their use of violence rose in a cumulative crescendo which concluded with the greatest collective annihilation ever registered in such a short space of time. The Second World War (with between 35 and 40 million deaths) then went on to far outstrip its older sister. It was the most violent century because this succession of events was accompanied by another, no less bloody and foundational, series of civil wars and internal conflicts. It was the most violent century because, despite everything that had happened prior to 1945 , the most summary of proceedings, mass executions, dictatorships implemented and maintained through civilian bloodshed were all pursued and even perfected in Europe: in no small number of cases continuing with the dynamics established in the first half of the century; in others, with new dynamics; and, in the case of Greece, serving as a link between the two.

Unlike many of the works devoted to the interpretation of the mechanisms of contemporary collective violence (and in particular to the concept of genocide), I do not consider it useful to highlight one, or the, "correct" way of interpreting or naming that past. There are often attempts to provide elements of analysis that lead to a unique definition or conceptualization, merging complex, and often distant, violent processes in omni-comprehensive narratives and interpretations. Faced with the (possibly vain) hope for predictability and the generalized decontextualization of analyses of violence which have been made in many areas of political science, but are particularly obvious in the study of civil wars (see Newman, 2014 and Collier and Sambanis eds., 2005), current historiographical analyses on collective European violence have started to reach a significant degree of sophistication, claiming ownership of a comparative perspective that requires extensive linguistic, theoretical and historiographical knowledge. To cater for this need for historical contingency without renouncing theoretical complexity, I have proposed the term politics of violence by way of conceptual umbrella. Without wishing to open a Byzantine debate focusing on issues of terminology, I feel that the name politics of violence better encompasses, with fewer assumptions and more nuances, what we are analyzing here: the mechanisms, the politics which, at the theoretical and practical levels, different states, state agencies or groups used to access, control, monopolize and influence power through violence. It therefore implies the existence of specific political practices whose theoretical content and practical materialization occurred through violence. Of course, here too, we need to specify what is meant by politics and what is meant by violence. In reality, this is perhaps one of the most complex debates on the contemporary age.

The last two decades have been universally devoted to the era of the victim of violence and to the victim as an absolute category. However, for the purposes of understanding collective violence, it is more enlightening to explore the motivations of the perpetrators. And it is this comparison that is so difficult to tackle. Perhaps the first thing to do is to identify this perpetrator, and ask ourselves to what extent the things we take for granted are merely half-truths, widely accepted in view of the difficulty of knowing more thoroughly the situations that lead to collective violence. To achieve this, context is essential, but it is not everything. And, on their own, they certainly do not answer the most complex question we should ask about the processes of mass violence in twentieth-century Europe, namely "Why?". The death of another individual is, undoubtedly, one of the most radical and far-reaching decisions another human being can make. It entails crossing, or having previously already crossed, thresholds of such extreme dis-empathy towards the other that, for the most part, historiography has not -we have not- even began to glimpse them. Rather than the reassuring and widespread tendency of de-personalizing violence a posteriori by explaining it on grounds of context, the received order and collective guilt or by reducing it to barbarism, destruction, madness and futility, there are much more complex and, if we wish, disturbing answers. Exploring the whys and wherefores of this violence implies immersion in ideological, identity, cultural, political and economic plots in local, regional, supraregional, national and supranational contexts. Beside these contexts stand decisions and intentions, also in the use of force, killing, exploitation, deportation or repression. And this is where the visions of violence based on projection (the omnipresently destructive master plan or due obedience), moral conventions (evil for evil's sake, absolute destruction) or pathological archetypes (madness, illness), fail. The problem resides in offering an alternative interpretative mechanism.

Observing violent processes and analyzing them as a whole, approaching them from their multifactual praxes, through the languages that cloaked them and the interpretations (mainly positive) developed around them, is key to placing them in context and to understanding the historic and interpretative relationship that can be established between them. We have to demonstrate the differences and the continuities, to understand how and why they start, how and why they develop and how and why 
they end. We have, in short, to understand the mechanisms and the intellectual and identity logic represented and which gain shape, meaning and historical praxis in the act of identification and collective violence. Twentieth-century collective violence did not, in most cases, pursue destruction as ultimate goal, but was seen as a means to achieving a "higher" purpose: to cleanse the soil, the country, the community and its subjectivities (Das, 2007; Das et.al. eds., 2000), by what was seen as the necessary, healing and proactive elimination of the enemy. This does not, of course, mean that all collective violence in twentieth-century Europe had an elaborate, positively-projected objective, be it the improvement of race or society, or the protection of a threatened national community. The violence of the post-Second World War period -that of the groups massacred during the war, that of the Soviet soldiers against the defeated enemies or that of partisans and guerrillas- often reveals an openly vengeful nature. This complacent and benevolent view of violence -as necessary, healing and proactive- was not the exclusive preserve of any country or historical process. But it was always a performative process.

However, none of this can lead us to conclusions about the predictability of the future. As we are reminded by Weiss-Wendt (2008: 63), the Darfur massacres took place at the moment of greatest development of genocide studies. Knowing about Auschwitz did not deliver humanity from the mass killings of Cambodia or Yugoslavia. Moreover, if ethnic cleansing in the Balkans was not enough to refute the aim of endowing analysis of the past with preventative validity, we should perhaps consider that, while social sciences were discussing the return of violence and the scientific nature of genocide and its unrepeatability (because, it was said, nobody would ever again permit the building of gas chambers and crematoriums in the context of humanitarian interventionism), several thousand Hutus were proving to the world, on live television, that no eichmanns or Wannsee conferences were necessary to devise a genocide. Decades of identification and stereotyping, years of heterophobia and a propitious context would suffice so that, where there were first pistols and then science, gas chambers and crematoriums, there could now to be machetes and clubs.

\section{NOTES}

1 Javier Rodrigo is Ramón y Cajal research fellow assigned to the project "Las alternativas a la quiebra liberal en Europa: socialismo, democracia, fascismo y populismo (1914-1991)" (HAR201125749) [The alternatives to liberal collapse in Europe: socialism, democracy, fascism and populism] at the Universitat Autònoma de Barcelona. This article contains some of the ideas expressed by Javier Rodrigo (ed.) in Politicas de la violencia. Europa siglo $X X$, Zaragoza, Prensas de la Universidad de Zaragoza, 2014.

2 The title of this work refers to the adjectives used in the titles of the highly influential books by Mazower (1998), Snyder (2010) and Lowe (2012).

3 Works showing historiography's sensitivity to the category of genocide, its conceptual growth and limitations include those by Gellatelly and Kiernan eds. (2003); Bruneteau (2006); Bartov, Grossmann and Nolan eds. (2002); Totten and Parsons (2009); Sémelin (2007).
4 During the Fascist ventennio colonial internment camps existed in Libya and Somalia, and civil internment camps on the Italian peninsula. In the Libyan camps, according to Angelo del Boca (1988), some 40,000 people died from starvation, illness and subjection to forced labor. On the Somalian camps, see Labanca (2001), and others.

5 On violence in the First World War, see Kramer's seminal work (2007). Also Becker, Audoin-Rouzeau, Ingrao and Rousso eds. (2002); Becker and Audoin-Rouzeau (2000).

6 On Russia, see Mayer (2001); Brovkin (1994); Figes (2000: 609 and following). On Finland, Alapuro (1988); Upton (1980). Benchmark works on the war in Finland, by Manninen, Paavolainen and Ylikangas, are quoted by Alapuro (2002).

\section{REFERENCES}

Ahonen, Pertti et. al. (2008) People on the Move. Forced Population Movements in Europe in the Second World War and its Aftermath. Berg, Oxford and New York.

Akçam, Taner (2004) From Empire to Republic. Turkish NationalismThe Armenian Genocide. Zed Books, London and New York.

Alapuro, Risto (1988) State and revolution in Finland. University of California Press, Los Angeles.

Alapuro, Risto (2002) "Violence in the Finnish Civil War of 1918 and its Legacy in a Local Perspective". In Workshop Political Violence and Civil Wars, Florence, European University Institute.

Aleksandrowicz-Pedich, Lucyna and Pakier, Malgorzata (eds.) (2012) Reconstructing Jewish Identity in Pre- and Post-Holocaust Literature and Culture. Peter Lang, Frankfurt am Main.

Aly, Götz (1999) Final Solution: Nazi population policy and the murder of the European Jews. Hodder Arnold, London.

Aly, Götz and Heim, Susanne (2002) Architects of annihilation: Auschwitz and the logic of destruction. Princeton University Press, Princeton.

Aly, Götz (2006) La utopía nazi. Cómo Hitler compró a los alemanes. Crítica, Barcelona [2005].

Applebaum, Anne (2004) GULAG. Historia de los campos de concentración soviéticos. Debate, Barcelona.

Arendt, Hannah (1974) Los orígenes del totalitarismo. Taurus, Madrid.

Atanasoski, Neda (2013) Humanitarian Violence. The US Deployment of Diversity. University of Minnesota Press, Minneapolis and London.

Bacon, Edwin (1994) The gulag at war. Stalin's forced labour system in the light of the archive. Macmillan, London.

Baldissara, Luca and Pezzino, Paolo (editors) (2004) Crimini e memorie di guerra. Violenze contro le popolazioni e politiche del ricordo. L'Ancora del Mediterraneo, Napoli.

Baldissara, Luca and Pezzino, Paolo (2009) Il massacro. Guerra ai civili a Monte Sole. Il Mulino, Bologna.

Bartov, Omer, Grossmann, Atina and Nolan, Mary NOLAN (editors) (2002) Crimes of war. Guilt and Denial in the Twentieth Century. The New Press, New York.

Bartov, Omer (2008) "Eastern Europe as the Site of Genocide". The Journal of Modern History, 80: 557-593.

Battini, Michele and Pezzino, Paolo (1997) Guerra ai civili. Occupazione tedesca e politica del massacro. Toscana 1944. Marsilio, Venezia.

Becker, Annette and Audoin-Rouzeau, Stéphane (2000) 14-18. Retrouver la Guerre. Gallimard, Paris.

Becker, Annette, Audoin-Rouzeau, Stéphane, Ingrao, Charles and Rousso, Henry (editors) (2002) La violence de guerre 19141945. Éditions Complexe, Paris.

Becker, Annette (2007) "Le deportazioni dai territori occupati", in Gabriella Gribaudi (editor), Le guerre del Novecento. Napoli, L'Ancora del Mediterraneo, Napoli: 57-66.

Biondich, Mark (2011) The Balkans: Revolution, War, and Political Violence since 1878. Oxford University Press, Oxford.

Black, Jeremy (2012) War and the Cultural Turn. Polity Press, Cambridge. 
Bloxham, Donald (2008) Genocide, the World Wars and the Unweaving of Europe. Mitchell and Co., Vallentine.

Bloxham, Donald and Moses, Dirk (editors) (2010) The Oxford Handbook of Genocide Studies. Oxford University Press, Oxford.

Bloxham, Donald and Gerwarth, Robert (editors) (2011) Political Violence in Twentieth-Century Europe. Cambridge University Press, Cambridge.

Brovkin, Vladimir (1994) Behind the front lines of the Civil War. Princeton University Press, Princeton.

Bruneteau, Bernard (2006 [2004]) El siglo de los genocidios. Violencias, masacres y procesos genocidas desde Armenia a Ruanda. Alianza, Madrid.

Capeloa Gil, Isabel and Martins, Adriana (2012) Plots of War. Modern Narratives of Conflict. De Gruyter, Berlin-Boston.

Cattaruzza, Marina (2010) "Last stop expulsion. The minority question and forced migration in East-Central Europe: 1918-49". Nations and Nationalism, 16/1: 108-126.

Chenoweth, Erica and Lawrence, Adria (editors) (2010) Rethinking Violence. States and Non-State Actors in Conflict. The MIT Press, Cambridge and London.

Chestermans, Simon (editor) (2001) Civilians in wars. Lyne Rienner, Boulder.

Clifton Spargo, R. and Ehrenreich, Robert M. (eds.) (2010) After Representation? The Holocaust, Literature, and Culture. Rutgers University Press, New Brunswick, New Jersey and London.

Collier, Paul and Sambanis, Nicholas (editors) (2005) Understanding Civil War. Evidence and Analysis. Volume 2: Europe, Asia, and Other Regions. The World Bank, Washington DC.

Dadrian, Vahakn (1995) History of the Armenian Genocide. Ethnic Conflict from the Balkans to Anatolia to the Caucasus. Berghahn Books, Providence and Oxford.

Das, Veena, Kleinman, Arthur, Ramphele, Mamphela and Reynolds, Pamela (editors) (2000) Violence and Subjectivity. University of California Press, Berkeley, Los Angeles and London.

Das, Veena (2007) Life and Words. Violence and the descent into the ordinary. University of California Press, Berkeley, Los Angeles and London.

Davies, R.W. and Wheatcroft, Stephen G. (2004) The Years of Hunger. Soviet Agriculture, 1931-1933. Macmillan, London.

Deák, István, Gross, Jan T. and Judt, Tony (editors) (2000) The Politics of Retribution in Europe. World War II and its Aftermath. Princeton University Press, Princeton.

Del Boca, Angelo (1988) Gli italiani in Libia. Dal fascismo a Gheddafi. Laterza, Roma-Bari.

Della Porta, Donatella (1995) Social movements, political violence and the State. A comparative analysis of Italy and Germany. Cambridge University Press, New York.

Dondi, Mirco (2004 [1999]) La lunga liberazione. Giustizia e violenza nel dopoguerra italiano. Editori Riuniti, Rome.

Dower, John W. (2010) Cultures of War: Pearl Harbor / Hiroshima / 9-11 / Iraq. WW. Norton-The New Press, New York and London.

Dwyer, Philip G. and Ryan, Lyndall (editors) (2012). Theatres of violence. Massacre, Mass Killing and Atrocity throughout History. Berghahn Books, New York and Oxford.

El Kenz, David (editor) (2005) Le massacre, object d'histoire. Gallimard, París.

Faraldo, José M. (2011) La Europa clandestina. Resistencia a las ocupaciones nazi y soviética, 1938-1948. Alianza, Madrid.

Feierabend, Rosalind L. (1966) "Systemic conditions of political aggression: an application of frustration-aggression theory". Journal of conflict resolution, X/3.

Figes, Orlando (2000 [1996]) La Revolución rusa (1891-1924). La tragedia de un pueblo. Edhasa, Barcelona.

Friedländer, Saul (2010) El Tercer Reich y los judios, 2 Vols. (19331939) Los años de la persecución y (1939-1945) Los años del exterminio. Galaxia Gutenberg, Barcelona.

Fulvetti, Gianluca and Pelini, Francesca (editors) (2006) La politica del massacro. Per un atlante delle stragi naziste in Toscana. L'Ancora del Mediterraneo, Napoli.
Gellatelly, Robert and Kiernan, Ben (editors) (2003) The spectre of Genocide: Mass murder in historical perspective. Cambridge University Press, Cambridge.

Gerlach, Christian (2010) Extremely violent societies. Mass violence in the Twentieth-Century World. Cambridge University Press, Cambridge.

Gerolymatos, André (2004) Red Acropolis, Black Terror: The Greek Civil War and the Origins of Soviet-American Rivalry, 19431949. Basic Books, New York.

Goldhagen, Daniel J. (2010) Peor que la guerra. Genocidio, eliminacionismo y la continua agresión contra la humanidad. Taurus, Madrid.

González Calleja, Eduardo (2013) Las guerras civiles. Perspectiva de análisis desde las ciencias sociales. Catarata, Madrid.

Gribaudi, Gabriella (editor) (2007) Le guerre del Novecento. L'Ancora del Mediterraneo, Napoli.

Gurr, Ted Robert (1972) "The calculus of Civil conflict". Journal of Social Issues, 28/1: 27-47.

Holmqvist, Caroline (2014) Policing Wars. On Military Intervention in the Twenty-First Century. Palgrave Macmillan, New York.

Horne, John and Kramer, Alan (2001) German atrocities, 1914. A History of Denial. Yale University Press, New Haven and London.

Horowitz, Irving L. (1989) Taking Lives: Genocide and State Pow$e r$. Transaction, New Brunswick and London.

Jacobs, Janet (2010) Memorializing the Holocaust. Gender, Genocide and Collective Memory. IB Tauris, New York.

Jensen, Olaf and Szejnmann, Claus-Christian (editors) (2008) Ordinary People as Mass Murderers: Perpetrators in Comparative Perspectives. Palgrave Macmillan, London.

Judt, Tony (2005) Postwar: A History of Europe since 1945. Penguin Press, New York.

Kaldor, Mary (1999) New and Old Wars. Organized Violence in a Global Era. Polity Press, Cambridge.

Kallis, Aristotle (2005) Genocide and Fascism: The Eliminationist Drive in Fascist Europe. Routledge, London.

Kalyvas, Stathis N. (2000) "Red Terror: Leftist Violence During the Occupation". In After the War was Over: Reconstructing Family, State, and Nation in Greece, 1944-1960, edited by Mark Mazower. Princeton University Press, Princeton: 142-183.

Kalyvas, Stathis N. (2006) The Logic of Violence in Civil War. Cambridge University Press, Cambridge.

Katz, Steven T. (1994) The Holocaust in Historical Context. Vol. I. The Holocaust and Mass Death before the Modern Age. Oxford University Press, New York and Oxford.

Kershaw, Ian (2005) "War and Political Violence in Twentieth Century Europe". Contemporary European History, 14-1: 107-123.

Kévorkian, Raymond H. (2006) Le Génocide des Arméniens. Odile Jacob, Paris.

Klinhammer, Lutz (2006 [1997]) Stragi naziste in Italia, 19431944. Donzelli, Rome.

Korb, Alexander (2010) "Understanding Ustaša violence". Journal of Genocide Research, 12/1-2: 1-18.

Kramer, Alan (2007) Dynamic of destruction. Culture and Mass Killing in the First World War. Oxford University Press, Oxford.

Labanca, Nicola (2001) "L'internamento coloniale italiano". En I campi di concentramento in Italia. Dall'internamento alla deportazione (1940-1945), edited by Costantino Di Sante, Franco Angeli, Milano: 40-67.

Lottman, Herbert (1986) The Purge: The Purification of the French Collaborators After World War II. W. Morrow, New York.

Lowe, Keith (2012) Savage Continent: Europe in the Aftermath of World War II. Macmillan, London.

Lüdtke, Alf and Weisbrod, Bernd (eds.) (2006) No Man's Land of Violence. Extreme Wars in the 20 th Century. Wallstein Verlag, Göttingen.

MacDonough, Giles (2007) After the Reich. From the Liberation of Vienna to the Berlin Airlift. John Murray, London.

MacMillan, Margaret (2013) The War that Ended Peace. The Road to 1914. Random House, New York and London. 
Maffesoli, Michel (1979) La violence totalitaire. Essai d'anthropologie politique. P.U.F., París.

Mann, Michael (2005) The Dark Side of Democracy. Explaining Ethnic Cleansing. Cambridge University Press, Cambridge.

Mawdsley, Evan (1987) The Russian Civil War. Boston.

Mayda, Giuseppe (2002) Storia della Deportazione dall'Italia, 1943-1945. Bollati Boringhieri, Torino.

Mayer, Arno J. (2001) The Furies: Violence and Terror in the French and Russian Revolutions . Princeton University Press, Princeton.

Mazower, Mark (1994) Inside Hitler's Greece. The Experience of Occupation, 1941-1944. Yale University Press, Yale.

Mazower, Mark (1998) Dark Continent: Europe's Twentieth Century. Allen Lane, London.

Mazower, Mark (2002) "Violence and the State in the Twentieth Century". The American Historical Review, 107/4: 1158-1178.

Mazower, Mark (2008) Hitler's Empire. Nazi Rule in Occupied Europe. Allen Lane, London.

McFarlane, Leslie (1974) Violence and the State. Thomas Nelson \& sons, London.

McPhail, Helen (1999) The Long Silence: Civilian Life under the German Occupation of Northern France, 1914-1918. I.B. Tauris, London.

Melson, Robert T. (1992) Revolution and Genocide: On the Origins of the Armenian Genocide and the Holocaust. University of Chicago Press, Chicago.

Michaud, Yves (1980) Violencia y política. Ruedo Ibérico, Barcelona.

Midlarsky, Manus I. (2005) The Killing Trap. Genocide in the Twentieth Century. Cambridge University Press, Cambridge.

Millen, Rochelle L. (1996) New perspectives on the Holocaust. New York University Press, New York and London.

Mommsen, Wolfgang J. (1982) "Non-legal violence and terrorism in Western idustrial societies: an historical analysis". In Social protest, violence and terror in Nineteenth and Twentieth Century Europe, edited by Id. and Gerald Hirschfeld. McMillan, London: 384-403.

Moore, Cerwyn (2010) Contemporary violence. Postmodern war in Kosovo and Chechnya. Manchester University Press, Manchester and New York.

Morton, Stephen (2013) States of Emergency. Colonialism, Literature and Law. Liverpool University Press, Liverpool.

Moses, Dirk (editor) (2010) Genocide: Critical Concepts in Historical Studies, 6 vols. Routledge, Abingdon.

Moses, Dirk (2013) "Genocide". Australian Humanities Review, 55: 23-44.

Naimark, Norman M. (2010) Stalin's Genocides. Princeton University Press, Princeton.

Newman, Edward (2014) Understanding Civil Wars. Continuity and Change in Intrastate Conflict. Routledge, New York.

Núñez Seixas, Xosé Manoel (2001) Entre Ginebra y Berlín. La cuestión de las minorias nacionales y la política internacional en la Europa de entreguerras, 1914-1939. Akal, Madrid.

Parsons, Talcott (1964) "Some reflections on the place of force in Social process". En Internal war: Basic Problems and Approaches, edited by Harry Eckstein, The Free Press, New York: 33-70.

Pavone, Claudio (1991) Una guerra civile. Saggio storico sulla moralità nella Resistenza. Bollati Boringhieri, Torino.

Payne, Stanley G. (2011) La Europa revolucionaria. Las guerras civiles que marcaron el siglo XX. Temas de Hoy, Madrid.

Pezzino, Paolo (2007 [1997]) Anatomia di un massacro. Controversia sopra una strage nazista. Il Mulino, Bologna.

Procacci, Giovanna (1999) Dalla rassegnazione alla rivolta: mentalità e comportamenti popolari nella Grande Guerra. Bulzoni, Rome.

Rieber, Alfred J. (2003) "Civil Wars in the Soviet Union". Kritika: Explorations in Russian and Eurasian History, 4/1: 129-162.
Rodrigo, Javier (2014) (editor) Politicas de la violencia. Europa siglo $X X$. Zaragoza, Prensas Universitarias de Zaragoza.

Roshwald, Aviel (2001) Ethnic Nationalism and the Fall of Empires. Central Europe, Russia and the Middle East, 1914-1923. Routledge, London and New York.

Rovatti, Toni (2011) Leoni vegetariani. La violenza fascista durante la RSI. CLUEB, Bologna.

Rummel, Rudolph J. (1994) Death by Government: Genocide and Mass Murder since 1900. Transaction, New Brunswick and London.

Sanborn, Joshua A. (2005) "Unsettling the Empire: Violent Migrations and Social Disaster in Russia during World War I". The Journal of Modern History, 77: 290-324.

Sarkin, Jeremy (2011) Germany's Genocide on the Herero: Kaiser Wilhelm II, His General, His Settlers, His Soldiers. UCT Press, New York.

Schmid, Alex P. (1991) "Repression, State Terrorism and Genocide: conceptual clarifications". In State Organized Terror. The Case of Violent Internal Repression, edited by P. Timothy Bushnell et. al. Boulder, Westview Press.

Sémelin, Jacques (2007) Purify and destroy: the political uses of massacre and genocide. Columbia University Press, New York.

Shaw, Martin (2007) What is Genocide? Polity Press, Cambridge.

Slim, Hugo (2008) Killing Civilians. Method, Madness, and Morality in War. Columbia University Press, New York.

Smith, Helmut Walser (ed.) The Holocaust and Other Genocides. History, Representation, Ethics. Valderbilt University Press, Nashville.

Snyder, Timothy (2010) Bloodlands. Europe between Hitler and Stalin. Basic Books, New York.

Stannard, David E. (1992) American Holocaust. Columbus and the Conquest of the New World. Oxford University Press, Oxford.

Stone, Dan (editor) (2008) The Historiography of Genocide. Palgrave Macmillan, New York.

Stone, Dan (editor) (2012) The Holocaust and Historical Methodology. Berghahn Books, New York and Oxford.

Swain, Geoff (1996) The Origins of the Russian Civil War. Longman, London.

Thrift, Nigel (2006) "Immaculate Warfare? The Spatial Politics of Extreme Violence". In Violent Geographies. Fear, Terror, and Political Violence, edited by Derek Gregory and Allan Pred. Routledge, New York and London: 273-294.

Tomasevich, Jozo (2001) War and Revolution in Yugoslavia, 19411945: Occupation and Collaboration. Stanford University Press, Stanford.

Totten, Samuel and Parsons, William S. (2009) Century of Genocide. Critical Essays and Eyewitness Accounts. Routledge, London and New York.

Trifkovic, Srdja (2011) Ustaša. Croatian Fascism and European Politics, 1929-1945. The Lord Byron Foundation for Balkan Studies, Chicago.

Upton, Anthony F. (1980) The Finnish Revolution, 1917-1918. University of Minnesota Press, Minneapolis.

Valentino, Benjamin A. (2004) Final Solutions: Mass Killing and Genocide in the $20^{\text {th }}$ Century. Cornell University Press, Ithaca.

Voglis, Polimeris (2002) Becoming a Subject: Political Prisoners during the Greek Civil War, 1945-1950. Berghahn Books, New York.

Weiss-Wendt, Anton (2008) "Problems in Comparative Genocide Scholarship". In The Historiography of Genocide, edited by Dan Stone. Palgrave Macmillan, New York: 42-70.

Wiedmer, Caroline (1999) The Claims of Memory. Representations of the Holocaust in Contemporary Germany and France. Cornell University Press, Ithaca and London.

Yeomans, Rory (2013) Visions of Annihilation. The Ustasha Regime and the Cultural Politics of Fascism 1941-1945. University of Pittsburgh Press, Pittsburgh. 